\title{
INTEGRATED PAPER
}

\section{加熱時発生ガス質量分析法の開発に関する研究}

\author{
Development of Thermally Evolved Gas Analysis \\ by Mass Spectrometry
}

\author{
有井 忠 \\ Tadashi ARII \\ 株式会社リガク SBU 熱分析グループ Strategic Business Unit-Thermal Analysis, Rigaku Corporation, \\ Akishima, TOKYO, JAPAN
}

\begin{abstract}
Evolved gas analysis by mass spectrometry (EGA-MS) is well known as one of the thermal analysis methods for measuring the thermal behavior of evolved gases from a sample as a function of the temperature, which is controlled by a predetermined heating program. Presently, this method is recognized as a powerful tool for understanding the thermal pathways of materials. Since MS is a vacuum technique, in previous studies, many problems existed due to trade-offs between minimizing pyrolysate condensations and maximizing sample temperature/physicochemical measurement accuracy by efficient coupling of thermal systems with mass analyzers. In order to resolve these problems, several types of EGA-MS equipped with interface systems, which consist of capillary type and skimmer-type structures, have been developed successfully and investigated satisfactorily. This study can be summarized as follows:

1) A capillary interface structure that connects a sample chamber and a vacuum chamber for a simultaneous thermogravimetry mass spectrometry (TG-MS) system was modified to overcome condensation and memory effects and improve maintenance significantly. The effect of humidity on thermal decomposition of a sample was identified by TG-MS equipped with a specially designed furnace to prevent water condensation coupled with a humidity generator for adjusting the water vapor pressure in the atmosphere.

2) The applicability of EGA-MS using a skimmer interface system was expanded by adapting a pressure control function (PCF), which was devised for improving the serious structural disadvantage of the skimmer interface system.

3) Sample-controlled thermogravimetry (SCTG), by which the sample temperature is varied to maintain a constant rate of mass loss by controlling the furnace heating, has been successfully developed and applied to TG-MS. The demonstrated data proved that this novel feature improves the resolution and enhances the accuracy of identification and quantification, even for materials decomposing by consecutive reactions.

4) EGA-MS systems equipped with a photoionization (PI) attachment using a vacuum ultraviolet (VUV) deuterium discharge lamp as photon source have been developed successfully. It is proposed that the unique PI mass spectra obtained in real time by EGA-PIMS can satisfactorily characterize the decomposition products by only parent ions with no contribution as a result of fragmentation during ionization.
\end{abstract}

The design and construction of EGA-MS systems and their valuable applications are described briefly.

(Received May 7, 2008; Accepted May 20, 2008)

\section{1. 序論}

国際熱測定連合 (international confederation for thermal analysis and calorimetry: ICTAC) により, 熱分析

Correspondence to: Tadashi ARII, Strategic Business UnitThermal Analysis, Rigaku Corporation, 3-9-12 Matsubara, Akishima, Tokyo 196-8666, JAPAN, e-mail: t-arii@rigaku. co.jp

有井 忠, 株式会社リガク SBU 熱分析グループ， テ 1968666 東京都昭島市松原町 3-9-12

注：本研究は 2007 年度日本質量分析学会奨励賞を受賞した。 (thermal analysis) とは「物質の温度を調整されたプログ ラムに従って変化させながら，その物質（および/あるい は，その反応生成物）のある物理的性質を温度の関数とし て測定する一連の技法の総称」と定義される。この手法は, 広い温度範囲で起こる試料の物理的あるいは化学的変化を 短時間で測定できるため, 多くの分野で利用されている11. また，単に温度变化による物性の变化量を求めるのみなら ず，速度論的な解析が容易に行える特徴がある。しかしな がら, 熱分析で得られるデー夕は試料のマクロ情報である ため，変化を容易に観測できるものの，具体的に“ごのよ 
うな変化が起きているか”という試料の分子レベルでのミ クロ情報を得るには，分光法など他の測定法に頼らざるを えない。

1990 年代から, 熱分析と他の測定の複合測定により, 物質のマクロ現象をとらえつつ, ミクロな熱分析を行う試 みが活発に行わ机るようになった。この複合化には, 熱重 量測定 (thermogravimetry: TG) 中の発生気体分析 (加熱 時発生気体分析）を行う複合熱重量一発生気体測定 ${ }^{2}$ や, 示差走查熱量測定 (differential scanning calorimetry: DSC) 中の状態変化を X 線回折 (X-ray diffractometry: XRD) やフーリエ変換赤外分光 (Fourier transform infrared spectroscopy: FTIR) などで分析する同時熱測定3) などがあり, 試料内でどのような化学構造や物理構造の変 化が進行しているか, また, どのような化学種が生成揮発 しているかを調べられる大きな利点がある。このような複 合測定は, 新しい熱分析法として急速に注目されており, 今後ますます普及するものと考えられる。

本稿では, 近年までに最も広く普及した代表的な複合測 定である加熱時発生ガス質量分析法の開発に焦点を当て, 筆者が多くの共同研究者と行った研究例について述べる.

\section{2. 加熱時発生ガス質量分析 (evolved gas analysis- mass spectrometry: EGA-MS)}

熱分解反応では, 質量減少のみを測定しても反応が直接 反映されない場合がある，このような反応では，揮発しな いで残った成分の質量を測定する代わりに，揮発性生成物 の同定, 定量が必要之なる。これが加熱時発生ガス分析 (EGA) で，加熱によって揮発したガスの分析には質量分析 (MS), 赤外吸収スペクトル (infrared spectroscopy: IR) あるいはガスクロマトグラフィー (gas chromatography: GC) が使用される。これら EGA は TGあるいは熱重量示差熱分析 thermogravimetry-differential thermal analysis (TG-DTA) と直接接続されたものが最む大きく 発展した。なかでも, 質量分析法の高感度性, 選択性や迅 速性などの特性を活かした EGA-MS の利用が顕著で, TG-DTA-MS や TG-DTA/GC/MS を用いる研究が年々多 くなっている ${ }^{4)}$ 13). これには, 二つの特集号論文 ${ }^{14), 15)}$ の寄 与が大きい. 同様に, セラミックスの研究開発における TG-DTA-MS の重要性を強調した連載執筆16)をはじめと して, 無機, セラミックス分野での TG-DTA-MS の普及に 言及した文献も発表されている ${ }^{17}$.

\section{1 気体輸送のためのインターフェイス}

EGA-MS に扔いて, 試料上り発生する気体を MS に精 度よく導入するためには, 気体輸送のためのインターフェ イス（トランスファーライン）を必要とする. 現在市販さ れているほとんどの TG 装置には, MS や FTIR 之接続す る接続口をアタッチメント（アクセサリー）として設けて いるが, 接続インターフェイスまで装備しているメーカー は数が限られている。このインターフェイスにはさまざま な工夫が必要となり，この構造によって EGA としての精 度と感度が支配される ${ }^{18)}$. 測定雾囲気には, ヘリウムガス

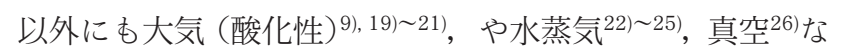
どが用いられる.ガスの導入インターフェイスの構造と測 定雾囲気とは目的とする測定分野によって選択される。一 般的な質量分析計は真空中で動作するため, 一部の真空中 での測定を除きこのインターフェイスは試料室 (大気圧) と真空チャンバとの間に圧力差をつくる構造でなくてはな らない，今日までにさまざまな EGA-MS 装置が提案され， それらの利点, 欠点や数多くのアプリケーションが報告さ れている. ガス導入インターフェイスの方式は，キャピラ リー型とスキマー型とに大別される.

\section{2 キャピラリー型インターフェイス}

キャピラリー型は, 熱分析装置と MS (GC/MS) 装置自 身にそれぞれ大きな改造を要さないため比較的よく用いら れる方式である，両装置間を一定の長さの細管（キャピラ リー）で接続し，この導入管を一定の温度で加熱保持する. 後にも述べるが, 熱分析装置とのインターフェイス部の着 脱操作は容易な構造でなくてはならないが, 反面, 接続部 分でのコールドポイントやガスリークの発生に最善の注意 を要する.

通常の MS 装置は, $10^{-3} \mathrm{~Pa}$ 以下の真空圧で動作するた め, インターフェイス管の内径と径路長は, MS 部の真空 圧の保持值に依存して選定される. 径路長が長くなると導 入管内でのガスの変質が懸念され，短くするとキャピラ リ一管径が小さくなり導入ガスに選択性が生まれやすくな る. 両者を最適化することに加え, 汎用機としての使いや すさやメンテナンス性を考慮して, $1 \sim 2 \mathrm{~m}$ 長程度で構築 した.

インターフェイス部の保持温度は, 導入ガスの再凝縮や 変質, 利用者への安全性を考慮して決定され, 汎用機では $300^{\circ} \mathrm{C}$ 程度を上限とした. したがって, ガス化生成物の沸 点がこれを超える場合は, インターフェイス部にガスが再 凝縮して内部にトラップされ, 測定対象外之なる. 他方, インターフェイス部の温度を $300^{\circ} \mathrm{C}$ 以上に増加させると 上述したように生成ガスの変質の問題が指摘される ${ }^{27)}$. こ 机は導入管内壁の劣化に伴亏活性化壁面との反応や生成物 間の再反応の促進に起因すると考えられる. 特に, 出発組 成が未知の試料の測定に際しては, 発生するガス種の沸点 の予測が難しいため, 測定後にインターフェイス部に生成 ガスがメモリーされてしまい, その後の測定結果にあ支障 をきたすことが多い。

以上の要因から，管内の污染等に対処するには，イン ターフェイスのキャピラリー管は, 接続部でのガスリーク の防止や管内の污染除去が容易な交換メンテナンス可能な 構造であることが必須となる。キャピラリー型のインター フェイスを用いて TG-DTA と MS， あるいはGC/MSを 接続したシステム構成例を Fig. 1 に示す.インターフェ イスの構造は, 内面を不活性処理したキャピラリ一管と, その外側に加熱ヒー夕を装備した保温管との二重管方式と なっている、キャピラリーは，MS（あるいは，GC/MS） 部之接続する 1 力所のみで機密シールされているため, 消 耗頻度に応じて, 簡便に交換メンテナンスができる ${ }^{28)}$. 
(a)
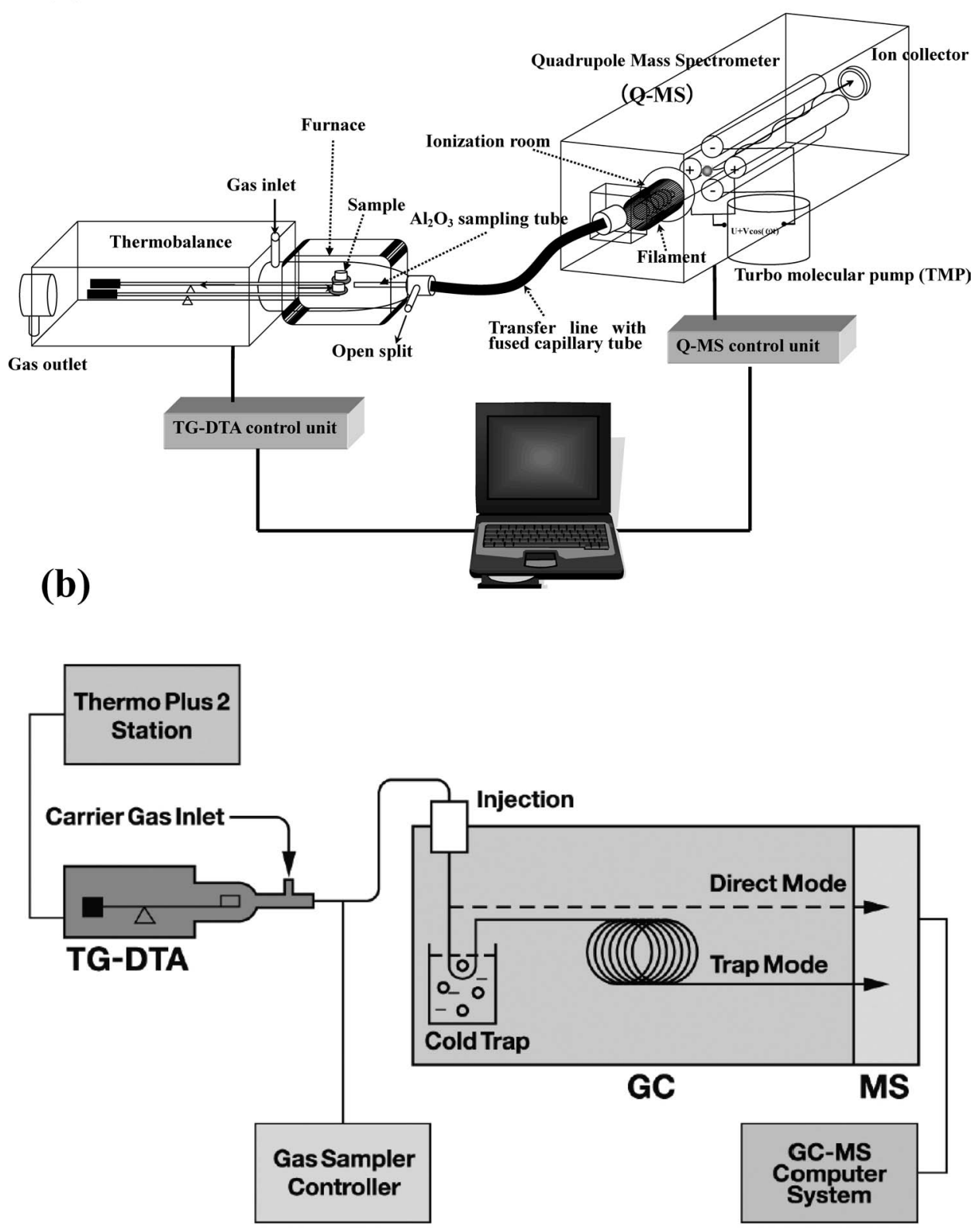

Fig. 1. Schematic diagrams of TG-DTA-EGA using a capillary interface. (a) TG-DTA-MS, (b) TG-DTA/GC/MS.

キャピラリー型のインターフェイスを有する EGA-MS が 飛躍的に発展，普及した背景には，このような簡便でかつ 確実な接続方法の確立に加えて著しく改善されたメンテナ ンス性の貢献が大きい.

\subsection{1応用例}

キャピラリー型 TG-MS は, 当初, 無機, セラミックス 分野を中心に利用されてきたが，近年では MS 本来の有用 性を期待した高分子の熱分解や機能性高分子材料や医薬品 などの有機化合物にも応用範囲が広がっている，特に，ポ リマーのキャラクタリゼーションには古くから熱分解ガス クロマトグラフィー (pyrolysis gas chromatography: PyGC) が活用されてきたこともあり，しばしば両者が対 比されることがある。一例として，ポリスチレン (NIST705) のヘリウムフロー中での熱分解を取り上げる. Fig. 2 は, 試料量 $25 \mu \mathrm{g}$ を $300 \sim 500^{\circ} \mathrm{C}$ の熱分解範囲にて急速加
熱（ステップ昇温）したときに生成する発生ガスを冷却卜 ラップし，GC/MS を行った TG-GC/MS のパイログラム である29). リテンションタイム $8.8 \mathrm{~min}, 18.8 \mathrm{~min}, 25.3$ min に特徵的なピークをもつ比較的単純な図形が観測さ れ, 既報の PyGC デー夕30),31)に類似する. 得られた total ion current (TIC) クロマトグラムの各ピークは，それぞ れスチレン単量体, 2 量体, 3 量体に相当する. 従来, ポリ スチレンの熱分解は, 生成ラジカルを基点として開始さ れ, 解重合 (depolymerization) するものとラジカルが分 子内を移動し解裂 (back-biting) するものが考えられてお り, 前者は解重合により単量体を, 後者はラジカルの移動 先によって 2 量体や 3 量体を生成すると解釈されていた. TG-MS に打いて異なる昇温速度 $\left(5^{\circ} \mathrm{C} / \mathrm{min}, 50^{\circ} \mathrm{C} / \mathrm{min}\right)$ の 条件下から得られた TG-derivative TG (DTG)-MS を Fig. 3 に示す. 昇温速度の変化に対応した単量体 $(\mathrm{m} / \mathrm{z}$ 


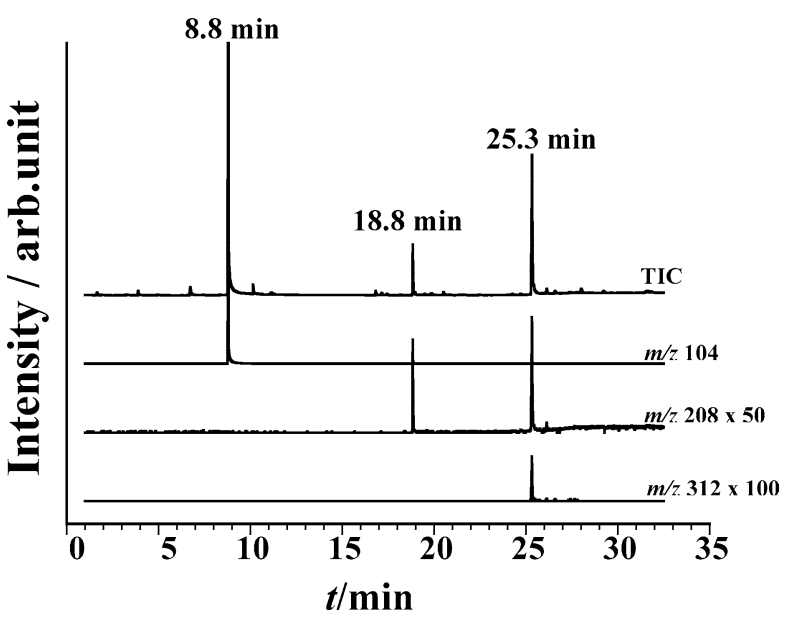

Fig. 2. TG-GC/MS pyrograms of polystyrene for evolved gas collected between 300 and $500^{\circ} \mathrm{C}$.

104), 2 量体 $(m / z 208), \quad 3$ 量体 $(m / z 312)$ の各分子のイ オンクロマトグラムの生成挙動を比較すると，3 量体の生 成は, 昇温速度の増加に伴い, 単量体および 2 量体とは明 らかに異なっている。このように, より高温域で生成を繰 り返す 3 量体の特異的な生成挙動は, 単量体と 2 量体の生 成メカニズムとは明らかに異なっていることを示唆してい る. 一方, 同時に得られた TG デー夕に基づいて, Friedman-Ozawa 法 ${ }^{22)}$, 33)による反応速度論解析を行い, 主鎖の ランダム解裂モデルより具体的な反応様式を解析したとこ ろ, ランダム解裂時に揮発する最小の高分子の集合度は 2 量体となり, 重量減少を起こすことが解析された。 以上の ことから, スチレン 3 量体の生成機構は, back-bitingに よるものでなく，主に 2 次反応によるものと推測でき， 3 量体の生成速度が単量体と 2 量体とは異なり, 昇温速度の 増加とともに高温側にシフトしたものと解釈できる。この ように, 分析法の複合化によって, 同時に得られる TGよ MS データからそれぞれ熱分解の反応メカニズムを解析 し, マクロとミクロ情報を統合, データを整合化すること で従来にも増して確度の高い分析結果を得ることが可能と なった.

\section{3 スキマー型インターフェイス}

スキマー型は,ノズルスキマーと呼ばれるジェットセパ レータ原理に基づく差動排気（ノズル，オリフィス）部を 熱分析装置の電気炉内部に組み込むことで, 長い導入経路 を要さない構造が最大の特徴となる ${ }^{34)}$.この構造ゆえに キャピラリー型に比べて多くの利点を有するが, 反面, 汎 用熱分析装置のアクセサリーとして簡便に着脱することは 困難となり，専用機として位置づけられる。

スキマー構造をもった EGA-MS 装置の構成を Fig. 4 に示す。スキマー部は, 外径が異なり, かつ先端に細孔を もった 2 種類の石英管を重㸚合わされて構成され, 外側の 管 (試料側) の先端細孔径は内側の管のそれよりあ小さい. 内側の石英管内部は MS 部のある高真空室に直結してお り, 二つの石英管の隙間はロータリーポンプで, 大気圧と 高真空の中間圧力に制御されている. 試料とスキマー部の
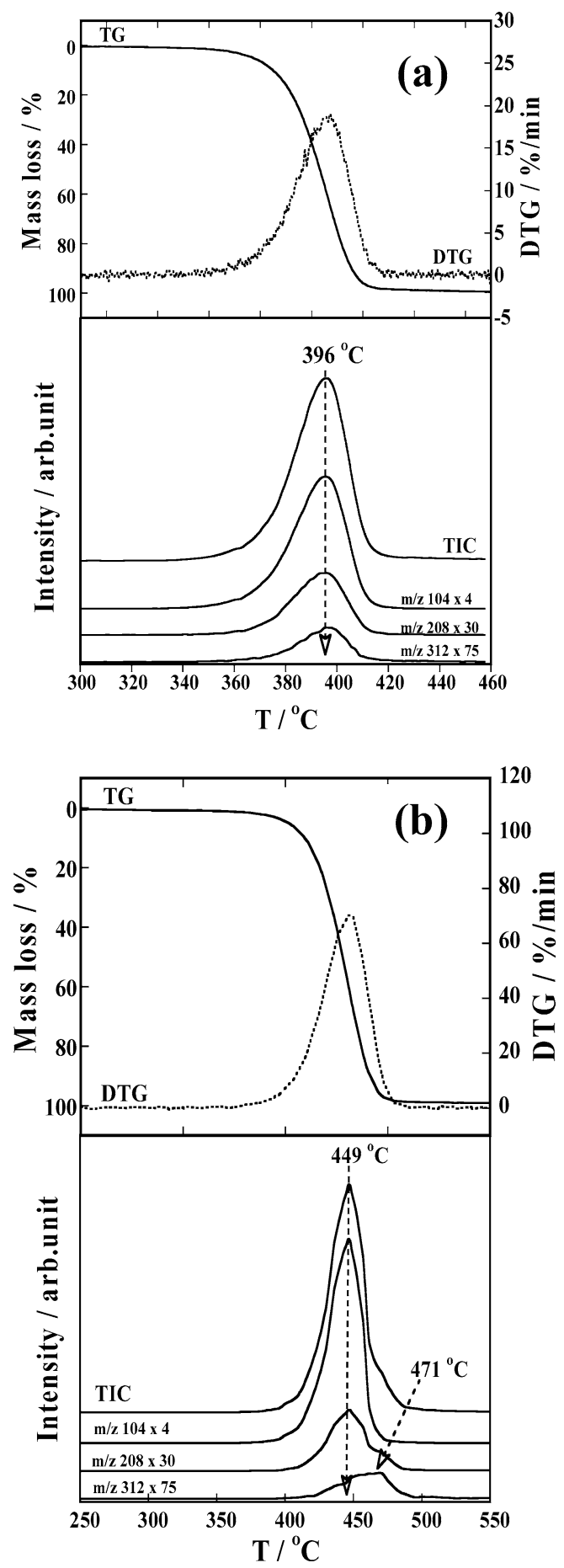

Fig. 3. TG-MS results of polystyrene in $\mathrm{He}$ at (a) $5{ }^{\circ} \mathrm{C} /$ min and (b) $50^{\circ} \mathrm{C} / \mathrm{min}$.

二つの細孔，およびイオン化源は，一直線上に配置されて いる. 加熱により試料から発生したガスは，キャリアガス とともにスキマー部に運ばれ, キャリアガスより重い質量 成分はジェットセパレータの効果によって MS 部で高感 度に検出, 分析される。

\subsection{1 特長}

スキマー型の差動排気部は電気炉の中のしかも試料直近 に配置されているので, ガス導入部の温度は試料温度と同 一環境下で加熱プログラミングされる. それゆえ導入径路 での発生ガスの再凝縮やガス变質, ガスリークなどの問題 


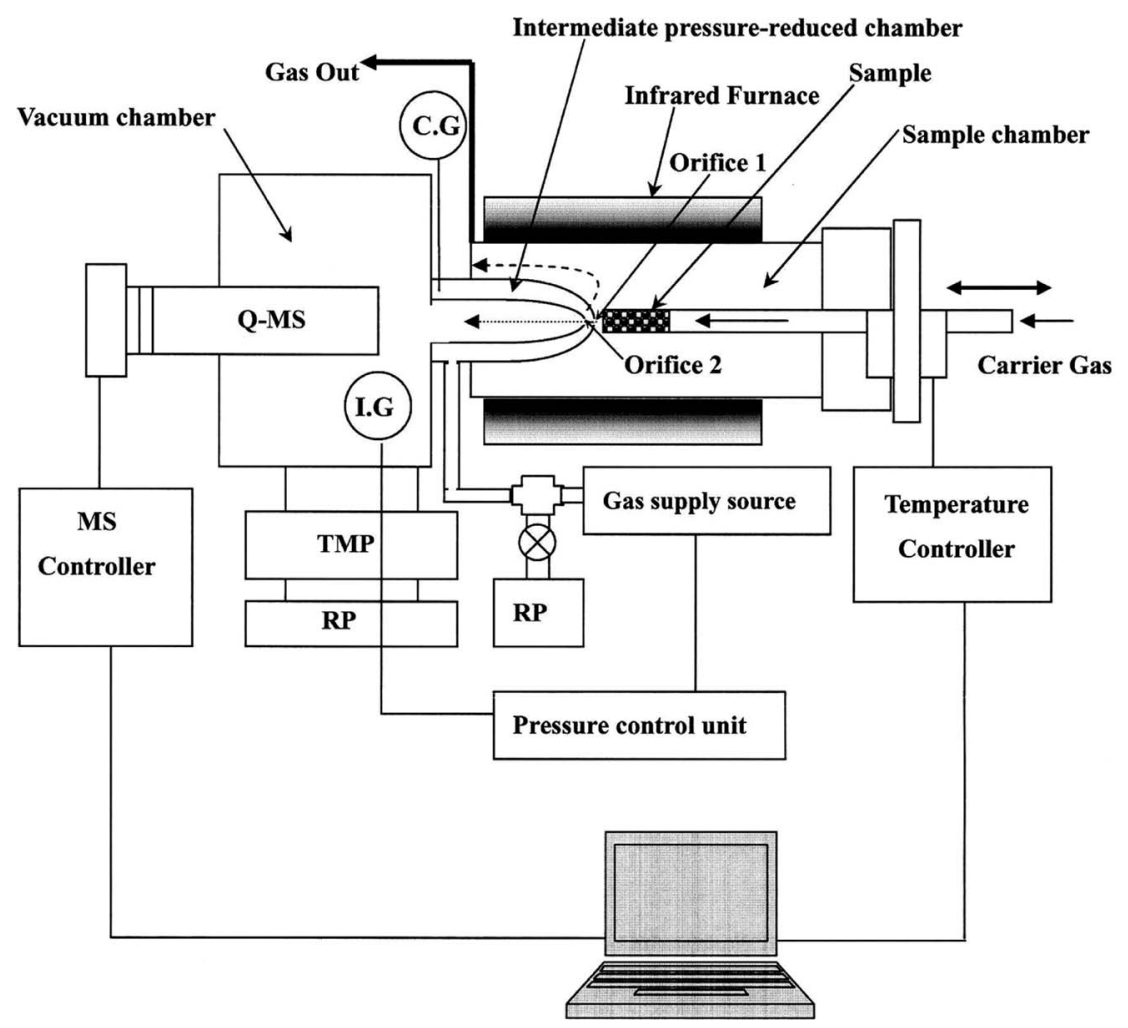

Fig. 4. Schematic diagram of EGA-MS using a skimmer interface with a pressure control function. I.G; ion gauge, C.G; crystal gauge, TMP; turbo molecular pump, RP; rotary pump

が少ない。また，キャピラリー型で制約となったインター フェイス保持温度以上の高沸点成分の測定にも対応でき, スキマー部は試料温度と同期して装置の最高使用温度まで 加熱できる.さらに，大気圧にある試料室と高真空室とを 接続するインターフェイス長が極小となるので高精度のガ ス分析が原理的に可能となる.

\subsection{2 構造上の問題点と解決策}

このように原理的にも優位性が高いスキマー型 EGA$\mathrm{MS}$ 装置 ${ }^{35)} 1980$ 年代に提案されたもののキャピラリー 型のような著しい発展を遂げることなく昨今に至ってい た.これは, 専用機的な性格や操作性にも問題はあったも のの, 実用面での基礎データの収集や検討が不足していた ことは否めない. 2004 年, 筆者らは上述したスキマー型 EGA-MS 装置を試作開発し基礎データを収集する段階で, 高温域での著しい感度低下を引き起こす重大な欠点に直面 した. 上述のように, スキマー型の特長は, 試料部近傍に 差動排気部を設置した構造によって, ガス導入部の温度を 試料温度と同一環境下で制御でき, その結果, 導入径路で の発生ガスの再凝縮やガス变質を抑え, また高沸点成分の 測定にも対応できる点である. しかしながら, 逆にこの構 造のために, 温度が上昇したときに差動排気部の圧力が低 下し, MS 部に導入されるガス量の減少と, それに伴う検 出感度の低下が引き起こされた。この構造上の問題は, MS 室に導入されるガス量をモニターし, この圧力指示值 が測定中に常に一定に制御されるように差動排気システム のガス供給系に信号をフィードバックすることによって解 決された ${ }^{36)}$.

\subsection{3 実例}

Fig. 5 は, シュウ酸カルシウム一水和物 $\mathrm{CaC}_{2} \mathrm{O}_{4} \cdot \mathrm{H}_{2} \mathrm{O}$ のスキマー型 EGA-MS 装置における圧力制御機能の有無 のデー夕比較を示したものである ${ }^{18)}$. 圧力制御を行わない 場合, 試料の温度上昇とともに MS 室の圧力が急速に低下 し, それに伴って TICのピーク強度が低下する.これに対 して, 圧力制御機能を用いた場合, MS 部の圧力は測定開 始時の $3.5 \times 10^{-3} \mathrm{~Pa}$ (この圧力值は任意变更が可能であ る）が常時維持され, その結果, 高温域でのガス検出感度 の低下が生じることなく, 広い温度範囲で安定した感度が 維持されている $400^{\circ} \mathrm{C}$ 以上での発生ガスの検出感度は, 圧 力制御機能を装備しない場合に比べて 2 倍以上に改善さ

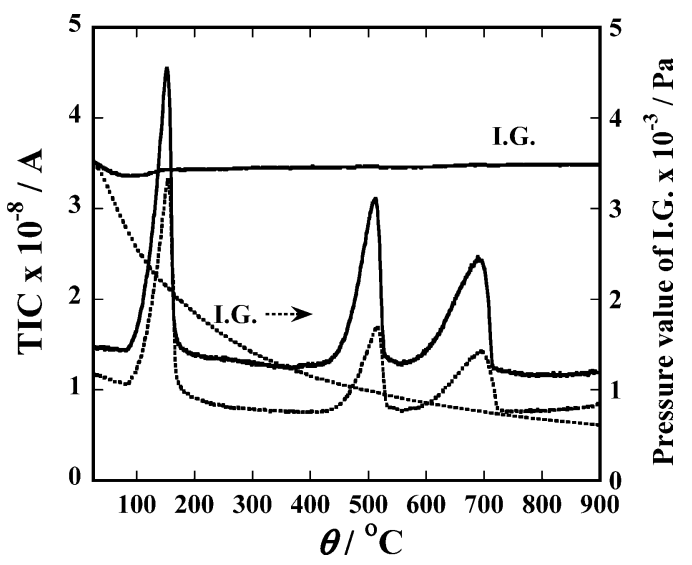

Fig. 5. Comparison of TIC curves together with pressure values obtained by EGA-MS with and without PCF. 
れており，スキマー型インターフェイスの特徴を生かした EGA-MS が可能となった。

EGA-MS の測定雾囲気ガス（キャリア）には, 多くの場 合, 発生気体成分之重複しないヘリウムガスが用いられる が，酸化性雾囲気で測定されることも多い，この場合，酸 素 $20 \%$ をへリウム中に混合した擬似空気ガスが用いられ る. 測定結果は, 熱分析曲線に加えて, 温度に依存したマ ススペクトルの変化を 3 次元的に描画 $(m / z$, イオン強度, 温度）することにより, 発生気体の分子種や組成の変化を 連続的に解析することができる.

\section{3. 速度制御熱重量分析 (sample-controlled thermogravimetry: SCTG)}

近年までの熱分析の進歩を特徴づけるもう一つの大きな 動きが，温度制御方式の多様化である。なかでも速度制御 熱分析法 (sample-controlled thermal analysis: SCTA) の発展は著しく, 急速に普及した。これまでの熱分析が, 等速昇降温を前提とした温度制御であったのに対し， SCTA 法は, 試料の物理的性質の変化速度を制御できるよ うにあらかじめ定めたプログラムで温度を变化させるもの で，「逆熱分析」あるいは「会話型の制御方式」と呼ばれる 新しい熱分析の概念である ${ }^{37)}$. 筆者は, 試料の質量減少速 度に合わせて温度を制御する試料速度制御 TG (sample controlled thermogravimetry: SCTG) を開発し, これを TG-MS に応用した ${ }^{38), 39)}$.

\section{1 特長}

SCTG では重量変化が始まると温度上昇が緩やかにな り，同じ反応機構でも，TGでは連続して観測される反応 が，何段階かの反応に分離されて観測される。この温度分 解能の向上が SCTG の大きな特徵である. 一方, 加熱温度 の自在な制御によって, 等速昇降温下における反応機構と は異なる反応機構が観測できるようになったのも SCTG のあう一つの特徴である.さらに, これと MS とを組み合 わせた SCTG-MS に拡張することで, 複雑で見過ごしてい た現象をMS においても分離測定できるようになった。こ の結果, TG の高分解能特性と MS の高感度特性とを両立 させる有効な手法となり, 複数の温度制御方式を組み合わ せることにより, 幅広い物質の加熱挙動の全貌を解明する うえで大きな役割を果たすことが示された30),31), 40) 45).

\section{2 応用例}

SCTG では, TGの問題となる自己冷却や自生雾囲気の 影響を抑えることが可能となる. Fig. 6 に, 有機金属錯体 である酢酸銅カルシウム 6 水和物, $\mathrm{CaCu}\left(\mathrm{CH}_{3} \mathrm{CO}_{2}\right)_{4} \cdot 6 \mathrm{H}_{2} \mathrm{O}$ の熱分解反応を TGとともに示した ${ }^{31)}$. TG と SCTG 曲線 を比較すると, 反応途中段階での減量率に明確な違いが現 れている. 無水和物の分解過程で, 両者で減量率が顕著に 異なる 2 段目の反応後の中間生成物を XRD 分析した結果 を Fig. 7 に示す. 減量率の差異は, 金属銅 $\mathrm{Cu}$ と酸化銅 $\mathrm{Cu}_{2} \mathrm{O}$ による分解生成物の違いとして観測されており, 熱 分解プロセスは明らかに異なっている。さらに, TG-MS により, この分解過程で生成するガス種を同時に分析した

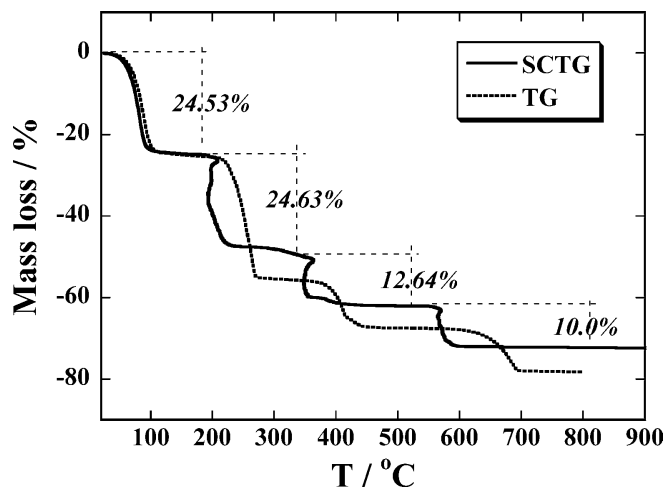

Fig. 6. Comparison of TG and SCTG curves for thermal decomposition of $\mathrm{CaCu}\left(\mathrm{CH}_{3} \mathrm{CO}_{2}\right)_{4} \cdot 6 \mathrm{H}_{2} \mathrm{O}$ in He.
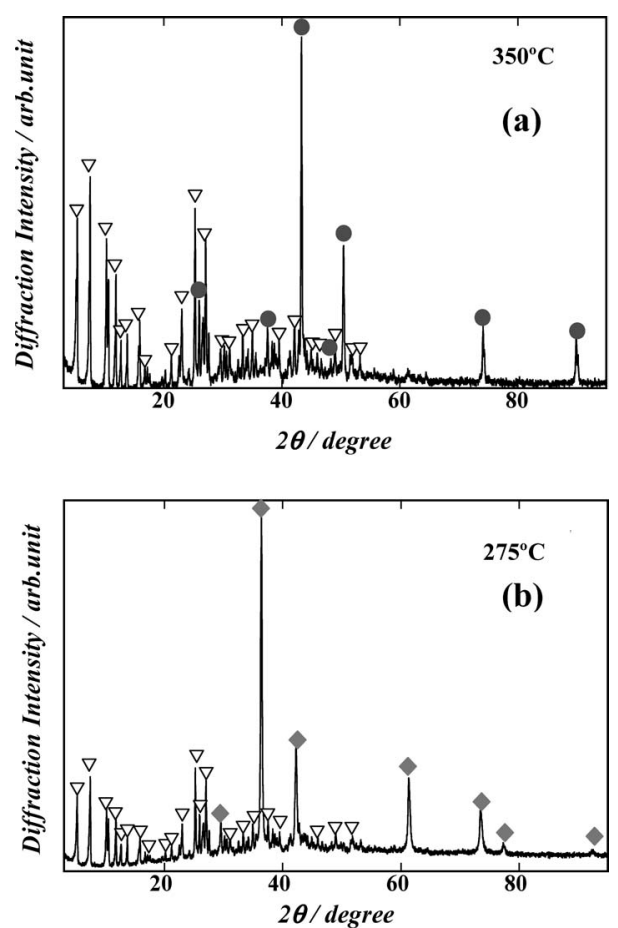

Fig. 7. Comparison of XRD profiles for quenching after the second stages in (a) TG and (b) SCTG. Key: (*), $\mathrm{Cu}_{2} \mathrm{O} ;(\diamond), \mathrm{Cu} ;(\bullet), \mathrm{Ca}\left(\mathrm{CH}_{3} \mathrm{CO}_{2}\right)_{2} \cdot 0.5 \mathrm{H}_{2} \mathrm{O} ;(\nabla)$

結果，上述した生成物に影響を与えうる一酸化炭素 CO の 生成が顕著に認められた。 すなわち, TG では分解生成気 体による自生雾囲気 CO の影響によって, 中間生成体であ る $\mathrm{Cu}_{2} \mathrm{O}$ はさらに還元されて $\mathrm{Cu}$ を生成するが, SCTG で は自生雾囲気の影響を受けにくく，しかも低温域にて熱分 解を進行させるため, 還元反応を引き起こさなかったと解 釈できる。このように，加熱温度を自在に制御することに よって従来法では見落としていた生成機構の解明や反応中 間体の生成などへの可能性が期待される.

\section{4. 調湿下の TG-MS および SCTG-MS}

熱分析測定は一般的に各種ボンベより供給される乾燥ガ ス雾囲気中で行われることが多いが，材料の動作環境に よっては湿度をパラメータとして熱分析を行うことが求め られる. 通常の TG で使用される電気炉の場合, 外部環境 


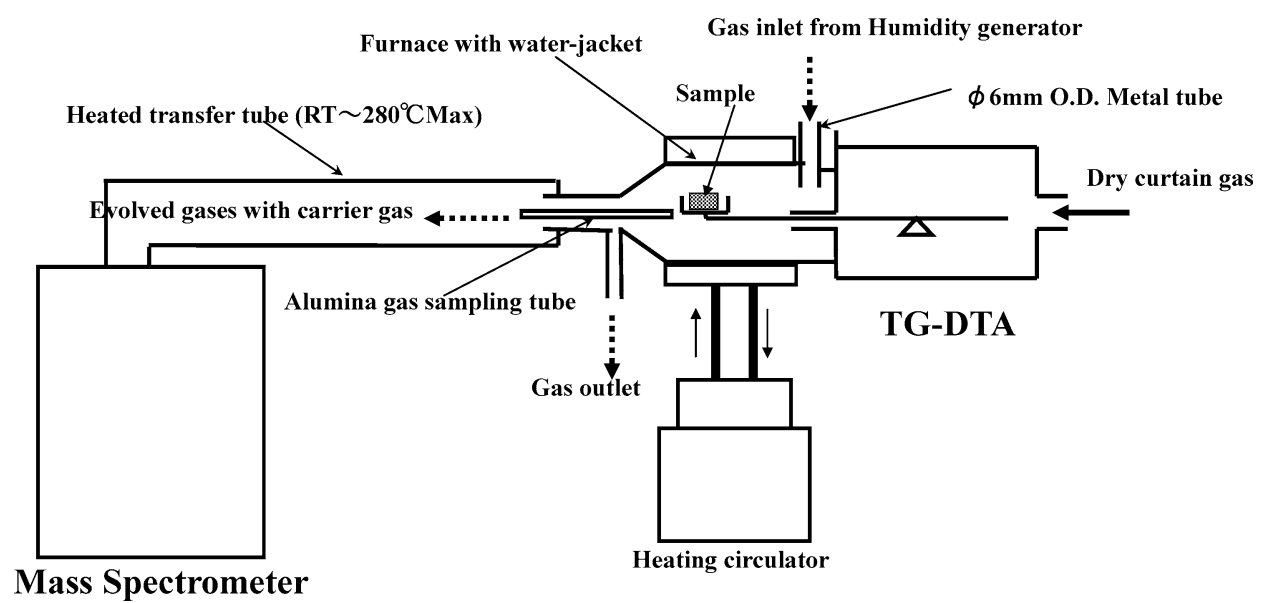

Fig. 8. Schematic diagram of humidity-controlled TG-DTA-MS.

温度の飽和水蒸気以上では系内で水蒸気が結露してしま い, 試料部まで目的湿度を保っことができない，そこで， 特に導入するガスの湿度 (水蒸気濃度) が室温の飽和蒸気 压を超える場合, 熱分析の装置構成を変える必要がある.

Fig. 8 は, 高濃度の水蒸気ガスを導入するための TG-MS 構成例である22)。このシステムでは, 加熱炉の外周に恒温 漕が設置されており, この恒温漕内に循環送水装置より所 望の温水を導入することで, 導入ガスの結露を防止する. 水蒸気発生装置から導入される水蒸気ガス濃度は， TG 装 置のガス導入口に設置した温度/湿度センサーによりモ二 夕ーされ, 目的值に調湿される。試料より発生したガスは, キャリア水蒸気とともにキャピラリー型インターフェイス を介して MS 部に導入され分析される.

\section{1 応用例}

Fig. 9 は，ポリブチレンテレフタレート (polybutylene terephthalate: PBT) の不活性乾燥雾囲気之調湿雾囲気中 (水蒸気分圧 $12 \mathrm{kPa}$ ) での $\mathrm{TG}$ 曲線の比較 (昇温速度 $2^{\circ} \mathrm{C}$ / $\left.\min , 5^{\circ} \mathrm{C} / \mathrm{min}, 10^{\circ} \mathrm{C} / \mathrm{min}\right)$ を示している ${ }^{24)}$. 水蒸気を導入 することによって重量減少に明確な差異が観測される。こ のとき, 測定後の残渣量は, 雾囲気中の水蒸気分圧の増加 とともに減少し, 水蒸気が熱分解反応に大きな影響を与え ていることがわかる。同様に，SCTGにより得られたデー 夕に基づいて反応速度解析を行ったところ, 高濃度水蒸気 中での熱分解時の活性化エネルギーが大きく低下すること がわかり, 反応機構への影響も明らかになった。TG-MS による両雾囲気中での発生ガス分析の結果は, 乾燥ガス中 での熱分解生成物以外にテレフタル酸とブチレングリコー ルを新たに検出し, 加水分解反応が同時進行することを示 した.このように, ポリエステルでは, 雾囲気中に水蒸気 を導入することで加水分解を促進させ，残渣のない効果的 な熱分解を起こさせることができる。

一方，SCTG-MS が実用的に役立っているプロセスとし てセラミックスの脱バインダ工程が挙げられる ${ }^{38)}$. セラ ミックスのグリーン成形体から有機バインダを加熱により 除去する工程では, 熱分解時の発生ガスにより, 膨れやク ラック, 層間剥離, 有機残渣などの問題を引き起こしやす

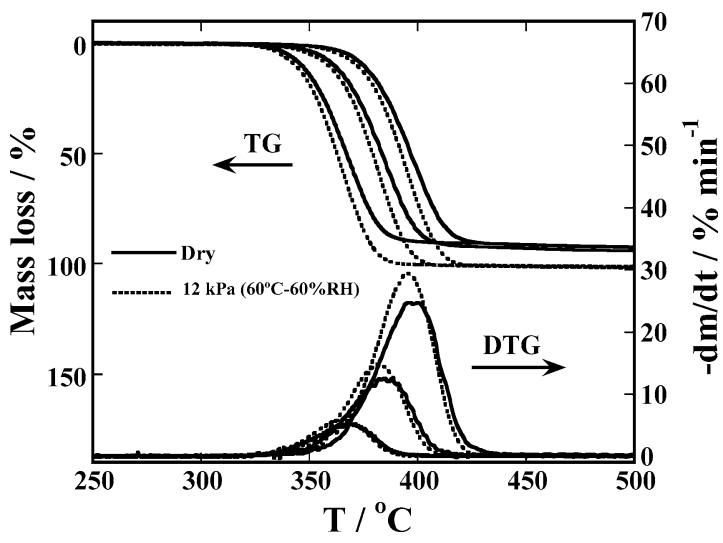

Fig. 9. Comparison of $\mathrm{TG}$ and DTG curves for PBT obtained at 2,5 , and $10^{\circ} \mathrm{C} / \mathrm{min}$ between dry $\mathrm{N}_{2}$ and $\mathrm{N}_{2}$ with controlled humidity $\left(P_{\mathrm{H}_{2} \mathrm{O}}=12 \mathrm{kPa}\right)$.

い。成形工程で重要な役割を果たすバインダをいかに，欠 陷を伴わないで除去するかが，セラミックス成形の重要な 課題である. SCTG の温度制御によって得られた緩やかな 脱バインダの時間-温度曲線ならびに, MS で分析される 化学反応の詳細情報によって, 多様なバインダの熱分解条 件や脱脂炉の効率的な運転条件を探索するうえで有用な結 果をむたらしている.

\section{5. 加熱時発生ガス光イオン化質量分析 (evolved gas analysis-photoionization mass spectrometry: EGA-PIMS)}

質量分析計のイオン化法として, 電子イオン化 (electron ionization: EI) 法が主として用いられている. EGA-MS では，同時に生成する複合ガスを分析対象とし なくてはならないことが多く，この場合，マススペクトル が複雑になる欠点があり, デー夕の解粕に工夫を要する。 そこで，GC/MS を補間的に用いて生成ガスを分離, 測定 する TG-GC/ $\mathrm{MS}^{22)}$ が有効之なるが，発生ガスのリアル タイム性がなくなるほか, 成分の熱履歴の変化を勘案す る必要がある。筆者は, EGA-MS のイオン化源として重水 素ランプ $(\lambda=121.567 \mathrm{~nm}, h=10.2 \mathrm{eV})$ による真空紫外 


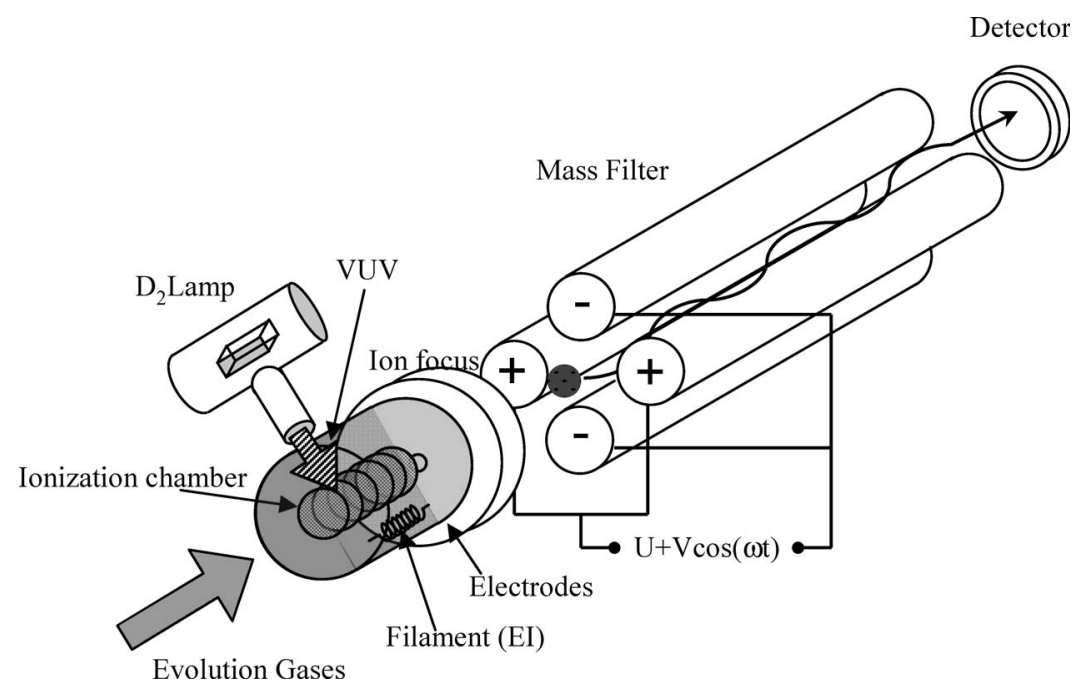

Fig. 10. Schematic drawing of a quadrupole mass spectrometer equipped with a VUV photoionization source. U; DC voltage, $V \cos (\omega t)$; high-frequency $\mathrm{AC}$ voltage

vacuum ultraviolet (VUV) 光源を組み込んだ加熱時発生 ガス光イオン化質量分析 (EGA-PIMS) 法を開発し, 複数 の混合ガス成分の分子イオンのみを効果的に観測するフラ グメントフリーのマススペクトルを得た ${ }^{46}$.

Photoionization (PI) 法は, 分子に光 (主に紫外線) を照 射し，その光子エネルギーが分子のイオン化エネルギーよ りあ大きい場合, 分子から光電子を放出させ, 同時に分子 をイオン化させるものである. PI 法は, 分子に過剩なエネ ルギーを与えることのないソフトなイオン化として期待で き, 照射する光の波長を適切に選ぶことで, 雾囲気ガス （窒素, 酸素, 水蒸気など）の妨害を受けずに有機ガスを選 択的にイオン化できるという特徴がある。これれより，ガ スの分子イオンスペクトルのみを観測でき, 同時発生する 多数の有機ガス成分をリアルタイムで弁別分析できる.

Fig. 10 に汎用の四重極型質量分析計にVUV 光源を搭 載した PI 質量分析計の構成を示す. VUV 光は, $\mathrm{MgF}_{2}$ 空 材を通してイオン化室に直接照射される。イオン源部には $\mathrm{EI}$ 源が装備されており, PI と EIを任意に選択, 切り換え が可能である ${ }^{47}$. このPI イオン化源は, 真空チャンバ内に 組み込む構成のため, キャピラリ一型, スキマー型イン ターフェイスを問わず EGA-PIMS として利用できる.

TG-PI/EIMS により, ベンゼン, トルエン, キシレンお よびアセトンをそれぞれ適量混合した溶剤サンプルから揮 発するガスを, PI 法打よび EI 法によって得られたマスス ペクトルの比較を Fig. 11 に示す ${ }^{46)}$. EI 法の場合, 個々の 分子イオンとフラグメントイオンのスペクトルが複雑に重 なり合うため, 混合しているガスの種類や成分数の特定が 困難となっている。一方， PI 法の場合では，フラグメン テーションを起こさずに分子のみをイオン化できるので, 観測されたマススペクトル中の 4 本のピークをアセトン $(m / z 58)$, ベンゼン $(m / z 78)$, トルエン $(m / z 92)$ 抢よびキ シレン $(m / z 106)$ として弁別できる. Fig. 12 は，それぞ れの成分ガスの発生挙動を 2 次元之 3 次元的に表示した TG-PIMS の結果である. 温度上昇に伴って脱離する各成
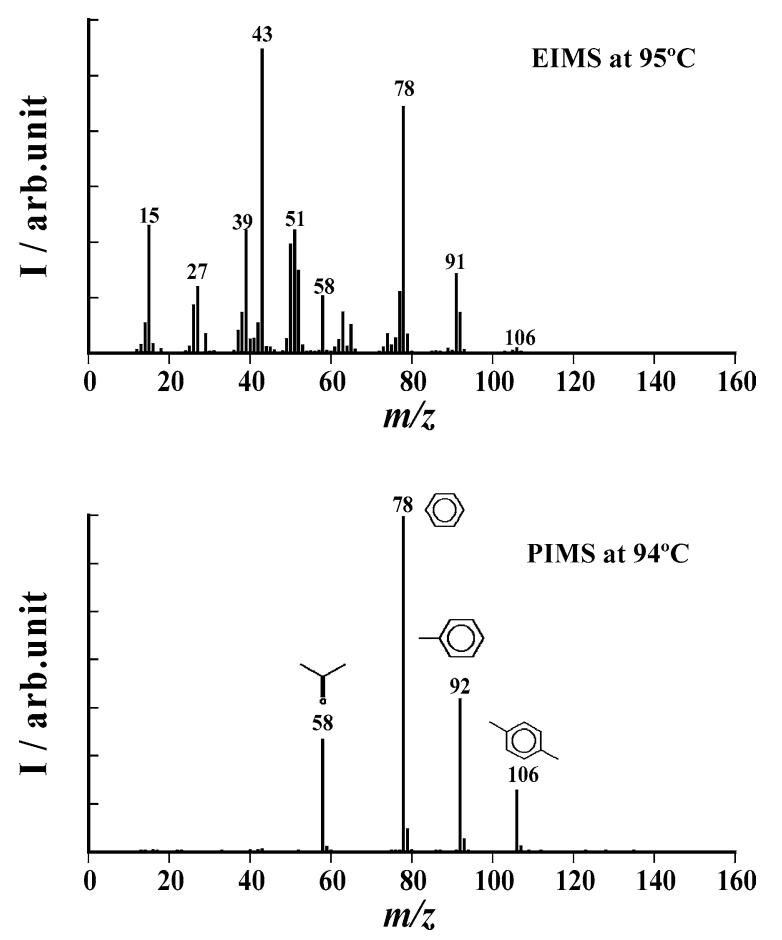

Fig. 11. Comparison of mass spectra of a sample mixture of acetone, benzene, toluene, and xylene obtained from each EI and PI mode by TG-DTA-PI/EIMS.

分の発生挙動を容易に概観することができる．このよう に, 分子イオンのみを生成検知するため, 発生ガスの経時 変化を容易に計測できる。 さらに，イオン化ェネルギーの 高い $\mathrm{H}_{2} \mathrm{O}(12.6 \mathrm{eV}), \mathrm{N}_{2}(15.6 \mathrm{eV}), \mathrm{CO}_{2}(13.7 \mathrm{eV})$ などの 雾囲気残留ガスがイオン化されないので, これらはスペク トル上に現れない。 ここに, 有機ガスのみを選択的にイオ ン化するPI 法のあう一つの有用な特長を見ることができ る.

\section{1 応用例}

加熱によって複数種の有機ガスが同時に発生する典型例 

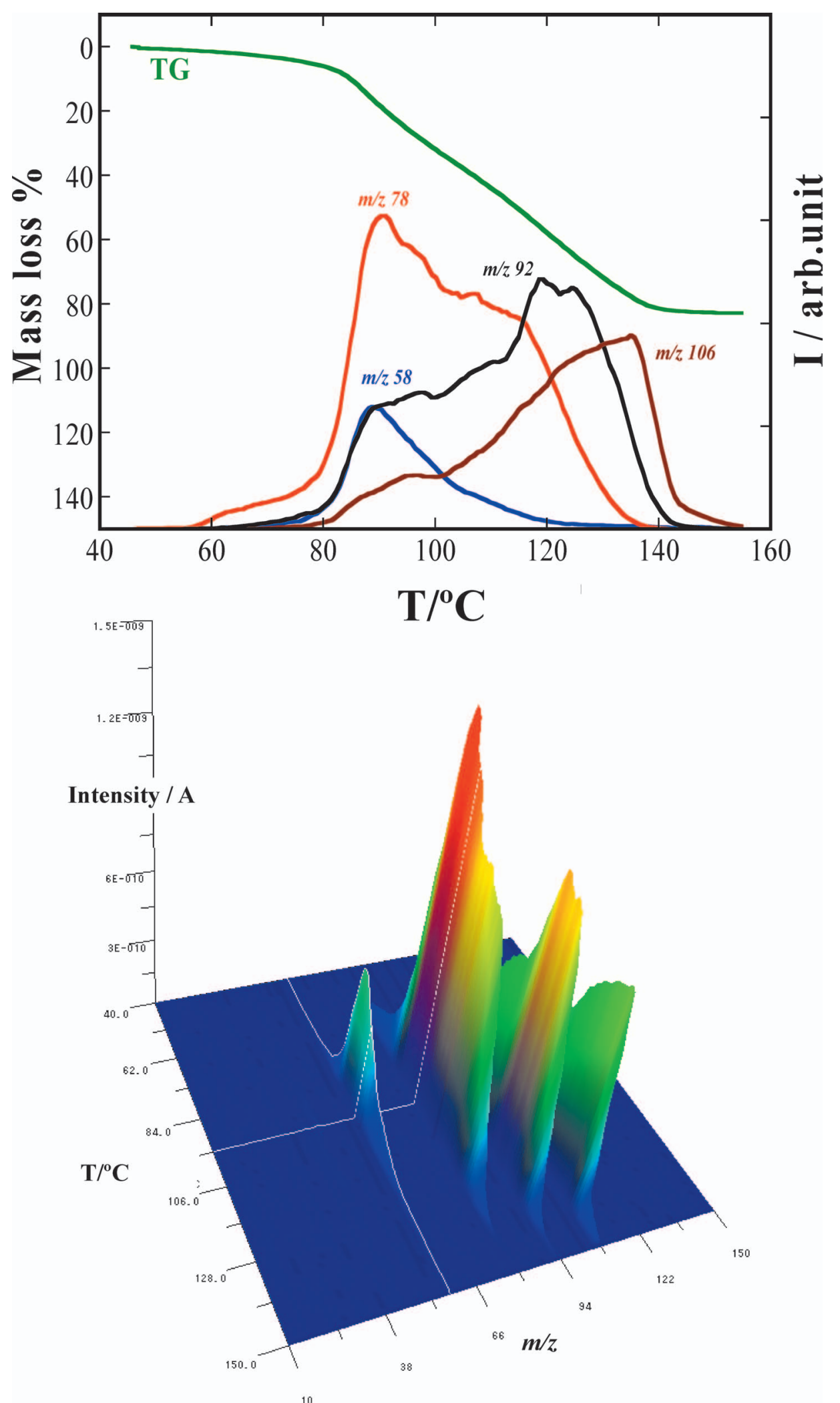

Fig. 12. TG curve and ion chromatograms of $m / z 58,78,92$, and 106 obtained by TG-DTA-PIMS for a sample mixture of acetone, benzene, toluene, and xylene.

が，ポリマーの熱分解である。ポリマーの熱分解キャラク タリゼーションを目的とし, 類似構造をもつ 3 種類のナイ ロンに EGA-EI/PIMS を適用し, その識別効果を比較, 検 討した結果が Fig. 13 と Fig. 14 である ${ }^{48)}$. 各 TIC クロマ トグラムのピーク温度域で得られた EI マススペクトル
(Fig. 13) は，分解成分のフラグメントイオン同士が低い $m / z$ 領域で互いに重なり合い, 類似したスペクトルとして 観測されるため, 個々のナイロンをこれらマススペクトル から直接, 特徴づけて識別することは困難である.これに 対して, PI マススペクトル (Fig. 14) は, サンプル間の異 

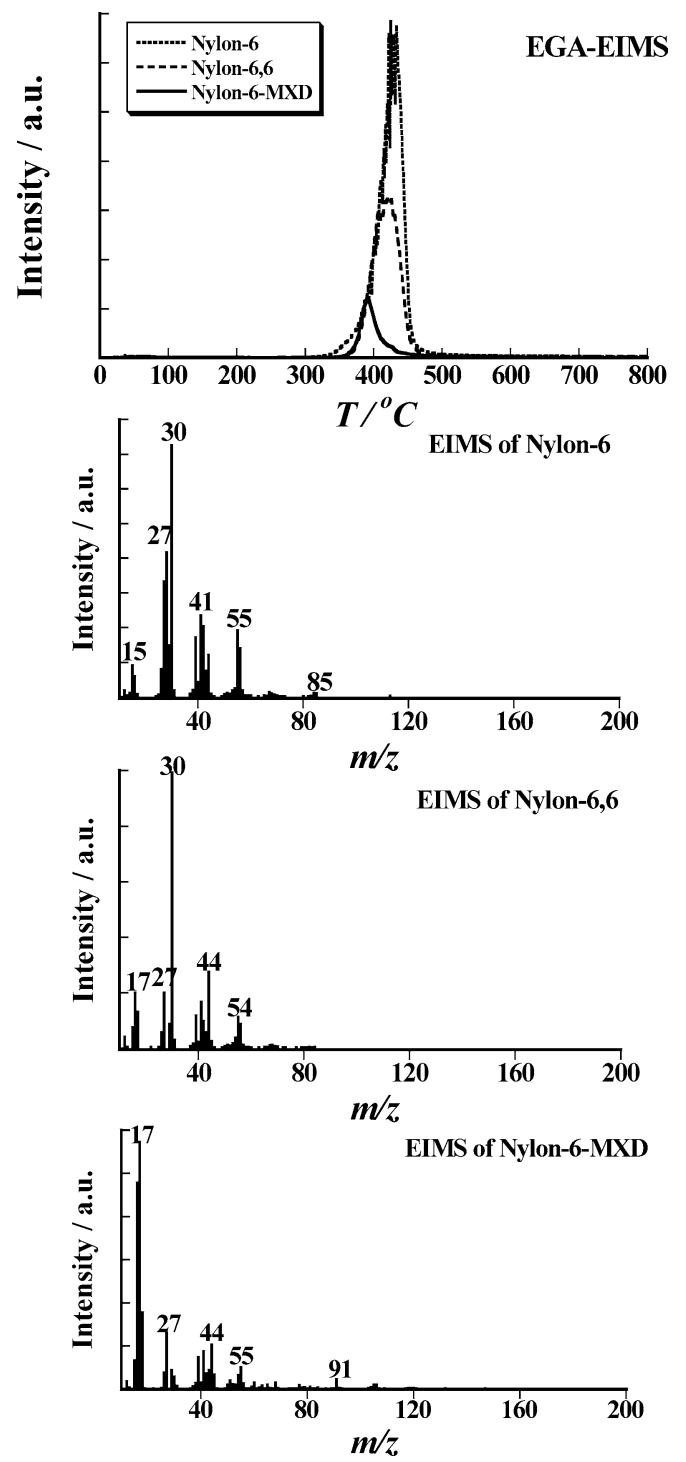

Fig. 13. Superposition of TIC curves obtained by EGA-EIMS for Nylon-6, Nylon-6,6, and Nylon-6 -MXD at $20^{\circ} \mathrm{C} / \mathrm{min}$ in helium atmosphere, and mass spectra obtained at maximum TIC peak temperatures.

なる骨格構造に起因した分解成分の分子イオンで構成され るため，各ナイロンは明瞭なスペクトルの違いとして観測 できる.ナイロン 6 は $m / z 113$ のカプロラクタム, ナイロ ン 6,6 は $m / z 84$ のシクロペンタノン, ナイロン MXD6 は $m / z 106$ のキシレンのイオンがそれぞれのマススペクト ルのベースピークとして特徴づけられている。このよう に, EGA-PIMS のフラグメントフリーな特性は, サンプル 間の微小な変化にも敏感に応答するため, 熱分解によりポ リマーを特徵づけ，認識することだけにとどまらず，サン プル中のごく少量の不純物の検出にも効果を発揮する46).

PIMS の登場により，従来困難とされていた有機化合物 の熱分解によって生成する混合ガス系の定性分析への幅が 広がり大きく進歩した. 他方, EGA-MS のニーズの中に, あう一つ重要な要素として, 定量的な解析がある. EGA-MS では, 特定の発生気体のイオンに対する検出信 号の大きさは, 妨害イオンがなければそのイオン量に比例
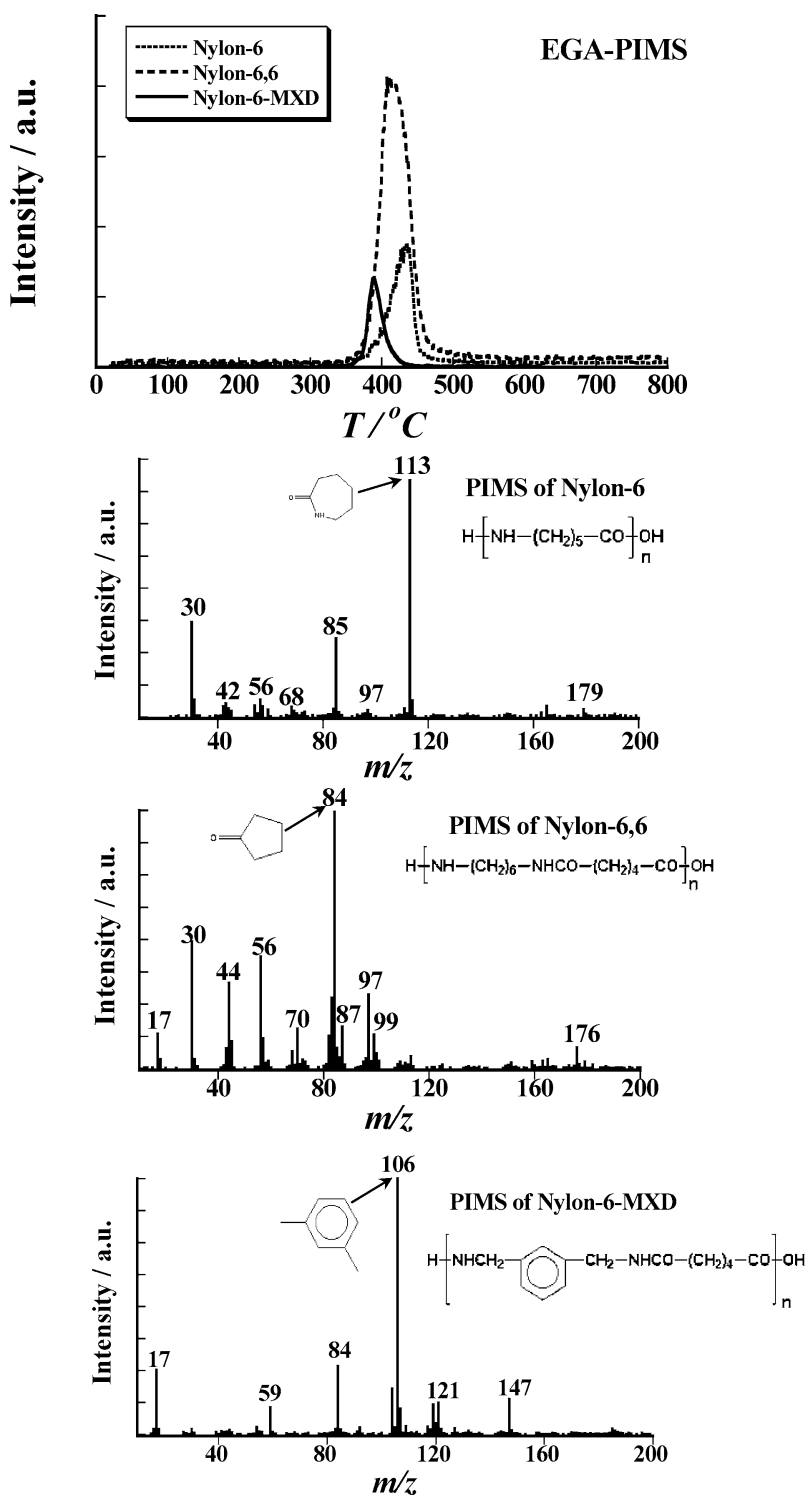

Fig. 14. Superposition of TIC curves obtained by EGA-PIMS for Nylon-6, Nylon-6,6, and Nylon-6 -MXD at $20^{\circ} \mathrm{C} / \mathrm{min}$ in helium atmosphere, and mass spectra obtained at maximum TIC peak temperatures.

し, 検出されたイオンクロマトグラムの面積から定量分析 が可能となる. PI 法では, 混合ガスの分子イオンのみが選 択的にイオン化されるため, 解裂イオンなどの妨害イオン の影響を原理的に受けにくい特長をもち, 今後は, 定量分 析にも大きく貢献することが期待される ${ }^{49}$.

$$
\text { 6. まとめ }
$$

EGA-MSの中でも, キャピラリー型のTG-MS とTG-GC/ MS は, 分析手法としての認知度も高まり, 各特徵を活か した分野で利用され，測定法としての成熟期に入ったが， 操作性を汎用熱分析装置なみに改善することや解析方法論 の確立といったハードとソフトのさらなる拡充が求められ る。一方, スキマー型 EGA-MS は, 構造に起因する感度低 下の問題点を圧力制御機能によって解決し実用的な手法と して製品化された。これにより活用頻度も増加し, 本来の 
特性を生かしたアプリケーションが多く導出されていくむ のと期待される.

他方, 発生ガスの導入が直接導入法であるがゆえの適応 範囲の制限は，速度制御熱分析 (SCTA) 法の活用や MS の ソフトイオン化法の進歩を背景に大きくその範囲を広げ, 今後ますます注目されていくであろう。

熱分解により発生するガスは活性が高く酸性, 腐食性な どさまざまな成分種となる場合が多く，イオン源やイン ターフェイス内面の劣化が起こりやすい. これらが改良さ れたほか, 調湿雾囲気中での測定も実用化されたことで, 汎用の熱分析としての利用は, さらに加速されるものと推 測される.

謝 辞 本稿は, 長岡技術科学大学大学院の博士課程か ら現在の(株)リガクで行ってきた加熱時発生ガス質量分析 の開発に関する研究成果をまとめたものです. 企業に属し ながらも研究の機会を与えてくださり，また丁寧なご指導 をいただきました長岡技術科学大学名誉教授の藤井信行先 生に深く感謝いたします。熱心にご指導してくださいまし た福井大学教授の伊佐公男先生をはじめとする諸先生方な らびに共同研究者の方々, また討論会や研究会を通じて貴 重なご助言を賜りました日本質量分析学会の会員諸氏に深 くお礼を申し上げます。一連の研究成果に対して, 2007 年度の日本質量分析学会奨励賞に推薦くださいました群馬 工業高等専門学校名誉教授の田島 進先生に深く感謝申し 上げます。

\section{参考文献}

1) 吉田博久, 小澤丈夫編, “最新熱分析”, 講談社, 東京 (2005), p. 3.

2) 伊佐公男，“熱量測定・熱分析ハンドブック”，日本熱測定 学会編, 丸善, 東京 (1998), p. 77.

3）吉田博久，“熱量測定・熱分析ハンドブック”，日本熱測定 学会編, 丸善, 東京 (1998), p. 85.

4) T. Arii, T. Senda, and N. Fujii, Thermochim. Acta, 267, 209 (1995).

5）伊佐公男，長谷川 寛，有井 忠，熱測定，22, 160 (1995).

6) 伊佐公男, 長谷川 寛, 有井 忠, 熱測定, 22, 221 (1995).

7) T. Kimura, H. Imamura, M. Sugahara, T. Arii, and S. Takagi, Mol. Cryst. Liq. Cryst., 276, 133 (1996).

8) T. Ozawa, T. Arii, and A. Kishi, Thermochim. Acta, 352353, 177 (2000).

9) M. Yamazaki, M. Kayama, K. Ikeda, T. Arii, and S. Ichihara, Carbon, 42, 1641 (2004).

10) R. Ozao, T. Arii, T. Okabe, D. Capogna, and M. Ochiai, Trans. Mater. Res. Soc. Jpn., 29, 2435 (2004).

11) R. Ozao, T. Okabe, T. Arii, Y. Nishimoto, Y. Cao, N. Whitely, and W.-P. Pan, J. Therm. Anal. Cal., 80, 489 (2005).

12) R. Matsumoto, T. Arii, Y. Oishi, and Y. Takahashi, Thermochim. Acta, 431, 53 (2005).
13) R. Ozao, T. Okabe, T. Arii, Y. Nishimoto, Y. Cao, N. Whitely, and W.-P. Pan, Mater. Trans., 46, 2673 (2005).

14) TMS 特集号, J. Mass Spectrom. Soc. Jpn., 46, 259 (1998).

15) Special issue, Thermochim. Acta, 295, 1 (1997).

16）澤田＼cjkstart豊，マテリアルインテグレーション， 12, 49 (1999).

17) 川路 均, 熱測定, 30, 225 (2003).

18) T. Arii, J. Mass Spectrom. Soc. Jpn., 53, 211 (2005).

19) T. Arii, Y. Sawada, K. Iizumi, K. Kudaka, and S. Seki, Thermochim. Acta, 352-353, 53 (2000).

20) Y. Masuda, Y. Seto, X. Wang, Y. Yukawa, and T. Arii, J. Therm. Anal. Cal., 60, 1033 (2000).

21) Y. Seto, K. Umemoto, T. Arii, and Y. Masuda, J. Therm. Anal. Cal., 76, 165 (2004).

22) T. Arii and A. Kishi, Thermochim. Acta, 400, 175 (2003).

23) T. Arii, A. Kishi, and Y. Sawada, J. Therm. Anal. Cal., 78, 639 (2004).

24) T. Arii and Y. Masuda, J. Anal. Appl. Pyrolysis, 71, 525 (2004).

25) T. Arii and A. Kishi, J. Therm. Anal. Cal., 83, 253 (2006).

26) 有井 忠，マテリアルインテグレーション，16, 69 (2003).

27) 有井 忠, 第 41 回熱測定討論会講演要旨集, p. 34 (2005).

28) 有井 忠, 特許第 3932007 号

29) 有井 忠, J. Mass Spectrom. Soc. Jpn., 51, 235 (2003).

30) T. Arii, S. Ichihara, H. Nakagawa, and N. Fujii, Thermochim. Acta, 319, 139 (1998).

31) T. Arii and Y. Masuda, Thermochim. Acta, 342, 139 (1999).

32) H. L. Freidman, J. Polym. Sci., C6, 183 (1964).

33) T. Ozawa, Thermochim. Acta, 31, 547 (1986).

34) T. Tsugoshi, M. Furukawa, M. Ohashi, and Y. Iida, J. Therm. Anal. Cal., 64, 1127 (2001).

35) E. Kaisersberger and W.-D. Emmerich, Thermochim. Acta, 85, 275 (1985)

36) T. Arii, Y. Takata, and S. Mastuo, European Patent, EP $1536452 B 1$.

37) 古賀信吉, “熱量測定・熱分析ハンドブック”，日本熱測定 学会編, 丸善, 東京 (1998), p. 75.

38) T. Arii, K. Terayama, and N. Fujii, J. Therm. Anal., 47, 1649 (1996).

39) 有井 忠, 岸 証, 藤井信行, 熱測定, 23, 5 (1996).

40) T. Arii and N. Fujii, J. Anal. Appl. Pyrolysis, 39, 129 (1997).

41) 有井 忠, J. Mass Spectrom. Soc. Jpn., 46, 374 (1998).

42) T. Arii, Y. Sawada, N. Kieda, and S. Seki, J. Mass Spectrom. Soc. Jpn., 47, 354 (1999).

43) S. Ichihara, A. Endo, and T. Arii, Thermochim. Acta, 360, 179 (2000).

44) T. Arii, A. Kishi, M. Ogawa, and Y. Sawada, Analyt. Sci., 17, 875 (2001).

45) T. Arii, T. Taguchi, A. Kishi, M. Ogawa, and Y. Sawada, J. Eur. Ceramic Soc., 22, 2283 (2002).

46) T. Arii, S. Otake, Y. Takata, and S. Matsuura, J. Mass Spectrom. Soc. Jpn., 54, 243 (2006).

47) 大竹智士，有井 忠，リガクジャーナル， 37, 28 (2006).

48) T. Arii and S. Otake, PITTCON 2008, 560-1P (2008).

49) 有井 忠, 本村和子, 大竹智士, 第 43 回熱測定討論会講演 要旨集, p. 160 (2007).

Keywords: EGA-MS, Capillary, Skimmer, SCTG, Photoionization 